\title{
Reiterating Indonesian National Identity in the Globalized World through a New Romantic Movement
}

\author{
Rahmawan Jatmiko \\ Department of Intercultural Studies, Universitas Gadjah Mada. Indonesia. \\ e-mail: rahmawan.jatmiko@ugm.ac.id
}

\begin{abstract}
This article discusses the possibility of re-evoking and invigorating romantic spirits to reiterate Indonesian national identity. This commences from the fact that despite its comparatively young age, Indonesia has experienced a number of heroic and romantic struggles, notable in our national history; for instance, the "national awakening movement" Boedi Oetomo in 1908, which became the first modern symbol of national struggle in Indonesia, the Sumpah Pemuda in 1928, which instilled in the youth's mind the three factors in common as our national identity, which binds our multi-cultural existence and experiences i.e. the unity of territory, language, and nation; and the third is Indonesian Declaration of Independence, $17^{\text {th }}$ of August 1945. This study starts from the assumption that those three symbols of struggle and identity are imprinted with romantic spirits, i.e. the sentimental feelings and emotions, which are no longer dealing with the worldly and materialistic considerations. In this discussion, one might question whether Indonesia has ever experienced any romantic movement as what European countries and America had in the end of the 18th century, yet that might not be so critical question in this case. Instead, what might be considered more important is another question such as, "do we need that kind of movement nowadays in order to clearly pronounce our identity?" By careful readings, observations and interpretations based on historiography and other references, this article sees that an attempt to give birth to our own Romanticism might be feasible as a good solution to rebuild our nationalism, since it also deals with recognizing and recalling our lost identity.
\end{abstract}

Citation: Jatmiko, R.: Enunciating Indonesian

\section{Keywords}

Romanticism, Emotion, Sentimentalism, Heroism, Patriotism, Nationalism, Identity.

through a New Romantic Movement In. D. Ekawati, et al (eds.): Proceeding of The American Studies International Conference 2018, Vol. 2, pp. 107-112. UGM Digital Press Social Sciences and Humanities, Yogyakarta (2019).

Published: May, 2019 


\section{Introduction}

The Romantic Movement in the 18th and 19th centuries is considered one of the biggest movements in human history which resulted in dramatic changes in people's viewpoints in many respects. It yields such feelings which are often related to emotion, sentimentalism, idealism, and immaterialism, which then hastens the birth of heroism, patriotism, nationalism in several levels - from the lightest such as courtesy and chivalry, to the extremes such as chauvinism and fascism (Guerard, 1934, p. 6; Lanyi, 1980, p, .145; Kravitt, 1992, p. 93)

Instead of creating primarily to please a patron or public, the romantic artist created mainly for selfexpression. Kravitt said that romantic art is introversive, generated by a consciousness of self, stimulated by and embodying the artist's own perceptions, thoughts, and feelings (1992, p. 93).

Historically, the Romantic movement was by no means spontaneous. Instead, it was influenced initially by great thinkers and philosophers in the preceding eras, such as Denis Diderot and Jean Jacques Rousseau. The movement was also greatly influenced by artists, and writers, who gradually built the movement in several aspects such as in arts and literature, philosophy, and politics. In our contemporary time, many believe that they are "the heirs" of the romantic spirits (Ackroyd, 2014).

As Guerard suggested in Herder's Spiritual Heritage: Nationalism, Romanticism, Democracy, the connection between romantic nationalism and democracy is easier to trace, yet there are still some contradictory notions. The first is that, at one period of its development, Romanticism was surely aristocratic, but in the main, the trend was the other way. Here Albert Guerard said by quoting Irving Babbitt that both Romanticism and Democracy are Rousseau's legacy. He said that it was the cosmopolitan culture of the social elite which Nationalism fought against (Guerard, 1934, p. 7)

This present analysis first starts from the assumption that Indonesians are overwhelmed and threatened by the powerful impact of globalization which finally can put our nation in such a difficult position, and that nationalism is something good to heal that problem.

Secondly, it believes that romanticism and nationalism are interrelated so that if we want to build or rebuild our nationalism, we need to initially be romantic. However, uncontrolled romantic sentiments can be devastating, because it tends to ignore logic. Those who are controlled by this feeling can act illogically as though they are under the influence of drugs. It is also stated that to be romantic is to have sympathy for madness. To illustrate the "madness" of romanticism, Samuel Taylor Coleridge, one of the big six-poets of English romanticism even reportedly used laudanum, opium mixed with alcohol, because he knew that human imagination has limits, and he wanted to transcend those limits (Ackroyd, 2014). Another poet who is not as popular as the big-six poet, Thomas Moore, used his poetry to highlight emerging issues of nationalism, of which verse frequently reflects upon the conditions of Irish-Catholic oppression and the failed Irish uprising of 1798. The fighting in the rebellion was marked by an extreme ideological yet illogical and increasingly sectarian bitterness.

In the context of American Romanticism, the American romantics approached the subject from a different perspective. Nevertheless, similar to that in Europe, American Romanticism set up opposition to the Neoclassic insistence on order and hierarchy by championing individual freedom through man's relationship to nature. The original state of the American wilderness, as well as areas of the country yet undeveloped, gave America a valid claim to a possession now desirable in European thought. While William Wordsworth's poem is a "man speaking to men"; by contrast, the American Romantic seems more to be a man speaking to himself. William Cullen Bryant stands in the American woods and dreams of a future civilization (Tanner, 1968, p. 102).

Wild nature thus became a source of national pride as the root of character traits for a unique national identity. Thus, in the American context, the interrelation between Romanticism and the idea of national identity can be observed. This study is to examine how the concepts of romanticism and national identity are applied in the Indonesian context.

Indonesia has experienced several heroic struggles and movements as previously stated. Those struggles and movements embodied nationalistic and romantic spirits. The national freedom fighters, notably the youths, at that time are said to be struggling and fighting with no rewards except their heroic and respectable names afterward. Hence, based on what previously stated, those struggles are seen as very sentimental and romantic. A senior Indonesian historian Taufik Abdullah has stated that the 
Indonesian Revolution was a "multi-complex revolution in one generation," full of energy, romanticism (Abdullah, 1972, p. 71).

\title{
2 Theoretical Framework
}

Is romanticism thus seen as a particular period of the history (of literature), or is it just considered as typology? (Lanyi 1980, p. 148) This paper relies on the latter so that it is just accepted to name any style, or movement, identical to the European and American Romantic movement in 18th and 19th centuries as another Romantic movement, which can take place in any place.

Historically, the birth of Romanticism in Europe was almost at the same time as the emergence of secularism and nationalism (see Ackroyd). It was the time of changing the center of attention or focus, from the externals (the universe) to the inner quality of individuals. In the age of reason, during most of the 18th century, the human was not in the central position. It was the era of dominations by the institutionalized religion, in this case, the church. The human had literally no control of power. God represented by the church seized all the power, and human seemed to lose their place.

It is tempting to establish a connection between that spiritual revolution and the other great movements which originated at the same time, Romanticism and Democracy. It might be shown, for instance, that Nationalism received much of its substance from Patriotism, which in its turn was colored by the Roman or classical tradition (Guerard, 1934, p. 6)

It is just fair to say for laypersons or academics that to be romantic is to place emotion, intuition and feeling above reason, logic and thoughts, and that also means to be undaunted with physical dangers if one can feel safe in his/ her own heart. Paulin Paris (as cited in Lanyi, 1980) stated that "the mysteries of human life," "infinity," and "the immaterial", all banned from classical literature, find their expression in romanticism (p. 149). This might be the one which gives birth to, as Kohn has put forward, the emotions which later enhance the spirit of patriotism and nationalism (Kohn 1950). This feeling is actually more general and is not restricted to identity and nationalism of a country. While, in a more globalized civilization, people tend to be more and more rationalistic and materialistic. Kohn further noted, "the arts of knights and guilds seem to the people at that time as a means of expressing the true national souls, its creative force not yet corrupted by rationalism which makes everything alike and which deprives it of life" (Kohn 1950, p. 443).

However, there are also several contrasts between nationalism and patriotism as what Guerard said as follows

\begin{abstract}
... that Nationalism is not recorded in English until the nineteenth century, although Herder used it freely in the closing quarter of the eighteenth. Far more elusive is the dating of an idea. Before achieving a name of its own, a concept may have been growing obscurely under the shelter of some other term. Thus, Nationalism is implicit in Patriotism, although the two are not synonymous. Now Patriotism, in some form, seems as ancient as mankind. (p. 1) It will be our endeavor to trace the rise of Nationalism, as distinct from Patriotism, on the eve of the French Revolution; to show its ramifications, and perhaps its deformations, within a few decades of its birth; and especially to inquire into the connection between Nationalism and the other two ideals which, exactly in the same period, were assuming consciousness: Romanticism and Democracy (p. 1).
\end{abstract}

In addition to discussing the contrasts between nationalism and patriotism, Guerard also stated that those three, nationalism, romanticism and democracy, are in the same realm of consciousness. This can be possible because they were in the same Zeitgeist or "spirit of the age", in that they were a reaction to the reduction and confinement of individual consciousness. Those three have similarities in emphasizing the importance of the individual. They are all human-centric.

\section{Findings and Discussions}

In an extremely globalized and modernized world, the materialistic attitude is so overwhelming that all people tend to overlook things which give them only immaterial values, such as unity, respect, peace, affection, harmony, and togetherness. Indonesian people are no exception. It seems when people in a country, notably a young democratic and developing country like Indonesia, is overwhelmed only by "physical development" there will be so much cost to be paid afterward. 
According to Leo Suryadinata, the concept of Indonesian nationalism did not mean the same thing to all Indonesian nationalists. For the secular Indonesian nationalists, it was a secular concept. The youth movement such as Boedi Oetomo reflected these divisions much more clearly than their adult counterparts. Adult nationalists at least succeeded twice in forming short-lived federations of political parties (P.P.P.K.I. and Gapi) but the youth organizations were never embraced by an overall federation (Suryadinata 1978, p. 102).

Suryadinata further explained that some writers have argued that Boedi Oetomo was the first Indonesian youth organization because of the role played by the students in its inception, while others have maintained that the dominant role of the students was short in duration and relatively insignificant because Boedi Oetomo experienced the greatest development only after it became an adult organization. Therefore, the latter group believed the first youth organization was the Tri Koro Dharmo (Three Noble Objectives), which was founded on 7 March 1915, seven years after the birth of Boedi Oetomo. This organization, which changed its name to Jong Java (Young Java) in 1918, was one of the most influential youth organizations before the mid-twenties (Suryadinata 1978, p. 102). Jong java was one of the first youth groups to initiate the birth of the Sumpah Pemuda in the second Youth Congress in 1928.

While the romantic characteristic of Sumpah Pemuda (Youth Pledge) might be appropriately seen in the following explanation by Musnandar in his book:

In 1926, the first Indonesian Youth Congress held Batavia (now Jakarta), resulted in no formal decisions but did promote the idea of a united Indonesia. On Oct 28, 1928, participant of the Indonesian Youth Congress [second congress] for the first time heard Indonesia Raya, the future national anthem composed by Wage Rudolf Supratman. The congress closed with the reading of the Youth Pledge ... The second Youth Congress [was] attended by representatives of the regions named themselves Jong Java, Jong Ambon, Jong Celebes, Jong Batak, Jong Sumatranen Bond Jong Islamieten Bond, Sekar Rukun, PPPI, Pemuda Kaum Betawi, etc (p. 83).

From that brief description, we can see that the situation at that time was sentimental. The Youth Groups from many areas in Indonesia started to be aware of their identity as one nation with common goals. However, some might say that the definition of the nation here is not something natural. Indonesia is a multicultural nation, covering a vast territory of land, seas and thousands of islands, and it is the romantic spirit that can create such imagination and sentiment. Therefore, once again, the spirit of romanticism is apparently portrayed in the second Youth Congress which resulted in Sumpah Pemuda (Youth Pledge) 1928.

The same is true with the Indonesian Declaration of Independence known as Proklamasi Kemerdekaan 1945. The short text read by Soekarno, countersigned by Soekarno and Mochammad Hatta is the most powerful text in our national history. Every Indonesian might shiver when they hear this text read, even not in a very formal occasion. That is also romantic and sentimental feeling in it, and the message is so powerful. It comes from "a powerful feeling" - if I need to quote Wordsworth's definition of good work.

Romantic Nationalism can be a powerful weapon to a nation in their struggle. On one hand, this is a really beneficial asset to the country, but on the other hand, the people must be aware of the fact that the war that saved the world for democracy secured the triumph of Romantic Nationalism, which can signify that there must be more and more wars, when people believe that it is a sentimental and heroic struggle. In addition to our national anthem, flag, heroic songs and slogans, Indonesian freedom fighters also had a romantic and "dreamy" symbol: the "bamboo runcing", the pointed, needle-sharp bamboo stick used as a spear during the battle. Some historians argue that this historical notion is not quite accurate, but people believe it is true and use it as the "mental power" to counter-attack the aggressors, at least psychologically. The portrayals of bamboo runcing are often seen in several popular historical movies depicting Indonesian pre-independence wars. The tales of bamboo runcing's victory against more modern armaments, whether it is valid or not, might have become sparks that ignited all youths' fighting against the colonizer in the battle to rage and fight with more flames of energy.

Looking back to one of the events in our national history called "Masa Bersiap" (ready stance), it was so unfortunate for European, Eurasian, Chinese community at that time, that the emotional responses as what Indonesian had during that period (1945-1947) could also result from romantic sentiments. In this case, it was created by Indonesian nationalist through incitement propaganda, which became "the catalyst driving the atrocities committed by Indonesian Pemuda armed with the considered mythical bamboo runcing against the native Eurasian civilian population". This drive was so powerful and destructive, yet illogical and irrational. Hence romantic feeling can also create something destructive and frightening, from a certain perspective. 
Reported by Isnaeni (2014) in an online Historia Magazine, in an interview, there was a questioned addressed to "Jenderal Besar" Abdul Haris Nasution "Did bamboo runcing really become a powerful weapon during Indonesian struggles? Or is it only a myth?

"It is a half myth" replied Nasution in Bisikan Nurani Seorang Jenderal, "in the first weeks after the declaration of independence, Indonesian masses carried the bamboo spears to force officers, factory workers, colonial elites and their families to comply the newly born Indonesian Republic. Yet, in many battles, according to Nasution bambu runcing functions more as symbolic weapon to burn the rage" ("Setengah Mitos Bambu Runcing") Thus, it can be seen that it also has a romantic meaning.

In many areas in Indonesia, bambu runcing monuments are built. This, according to Isnaeni, is to support national history glorification created by Orde Baru (Soeharto's New Order), and this might also reduce the significance of diplomatic struggles. In this view, many people will have a mindset that our independence is only attained by wars and battles ("Setengah Mitos Bambu Runcing"). This is an example of biased or illogical conception which may result from romantic beliefs.

Based on R.H.A. Saleh's explanation in Mari Bung, Rebut Kembali!, bambu runcing started to be used in Indonesia during Japanese colonial time known as takeyari. "Bambu runcing did not function as a primary weapon to fight the Dutch colonizers but it was used to protect civilian security and also to train local people to use bayonets since there were just limited number of rifles with bayonets according to Sewan Susanto in Perjuangan Tentara Pelajar dalam Kemerdekaan Indonesia (Susanto, 1985). From this description, it can be seen that the image creation of bambu runcing being described as a deadly weapon is inaccurate, yet it is significant to become "romantic energy" of Indonesian civilian combatants.

In addition, there are also numerous heroic figures who are subsequently attributed as national heroes. The elements of myths are apparent in giving a description to those heroes. For instance, the figure of heroic Prince Diponegoro, usually portrayed as a mounted warrior, typical European knights in the medieval era, yet his portrayal was also embellished with symbols of religion i.e. Islam. He was portrayed wearing a white coat, commonly worn by Islamic religious figures. This kind of spiritual-romantic description has given a huge impact on the later patriotism and nationalism. Whereas, Anderson suggested that a nice local example Prince Diponegoro in the 1950s was anointed as number one National Hero as if the Prince had led a movement for Indonesia's national independence from the clutches of Dutch colonialism (Anderson 1999, p. 1).

The previous statements might be in accordance with what Van der Kroef suggested:

What has been Diponegoro's influence upon the development of modern Indonesian nationalism? Insofar as that nationalism was influenced by a desire to revive the indigenous culture of the Indies, the answer is: considerable ( $p$. 449).

If we examine Van der Kroef's suggestion above, we can also relate this to one characteristic of romanticism that is the desire to glorify the past by the need for revival. In this case the demand for reviving the indigenous culture, which might be considered purer and more genuine. This is also in accordance with what Bright (1979) suggested,

\footnotetext{
"reverence for the past, a sense of nationalism, a preference for the natural and picturesque, a dedication to feeling as opposed to reason, aestheticism, and organicism are all traits that one commonly associated with Romanticism ..." (p. 386)
}

Van der Kroef further explained that ever since the beginning of the twentieth century, when the native movement in the East Indies got its start, the more extreme elements among Indonesian nationalist groups have looked to the figure of Prince Diponegoro, the early nineteenth-century mystic and leader of the native rebellion against the Dutch known as the Java War (1825-30), as a source of inspiration in their struggle for independence (p. 424).
... to the untutored Indonesian masses, Diponegoro has become personified with the Prince Liberator of legendary Javanese tradition and as such he is doubly important to Indonesian nationalists. Thus, his once much disputed career is again coming into prominence. In the absence of any complete work on Diponegoro, it is the purpose of this study to examine briefly the role he played in his country's history (p. 425).

The above illustration might explain how dreamy and romantic symbols could become a beneficial winning factor in our struggle. It also became a uniting factor of the struggle since we knew and realized it. This might also be true for our modern struggle. As we are now modernized, we are also getting more and more materialistic and we start to lose our romantic sense, which means that we have lost our beneficial winning factor. An attempt to give birth to our own Romanticism might be a good solution to rebuild our nationalism since it also deals with recognizing and recalling our lost identity. 


\section{Conclusions}

There have been some historical events and movements considered as powerful and influential to the later struggles, like what has been discussed before: 1) "Boedi Oetomo", 2) "Sumpah Pemuda", and 3) "The Proklamasi Kemerdekaan" or the declaration of independence. All those three can result from our nationalistic feeling, previously influenced by our romantic sentiments. In addition, some symbols of mythical power can only work when we really believe in it. We will be strong when we believe in, for instance, the supernatural power of certain figures or objects. That is why, in the end, this study believes that "a new" romanticism will give "extra fuel" to our development. If we become too materialistic and too worldly, we will never understand such feelings and emotions.

Therefore, if we must give the answer to whether we need to experience another romanticism, some might reply "we have had enough with that", and it is somehow wiser to say like that. However, if we really have a gut to try that again, I believe that romantic sentiments can be a very effective yet scary weapon to win any warfare. In addition, it might be an effective way to rebuild our national identity. Certainly, despite its success, there will be so much cost to be paid after a romantic revolution.

\section{References}

1. Abdullah, T. (1972) Review of Benedict R. O'G. Anderson, Java in a Time of Revolution: Occupation and Resistance 1944-1946 (Ithaca, N.Y.: Cornell University Press), in Prisma, II, No. 2 (April 1973), p. 71.

2. Ackroyd, P. [PhilosophicaLMindz]. (2014, Apr 9). BBC Romanticism "Liberty" Narrated by Peter Ackroyd. [Video File]. Retrieved from <https://www.youtube.com/watch?v=oLwRXISgiSQ\&index=1\&list=PLs3sz DgT77nQ kArw80fwqzHhLZpU2o>

3. Anderson, B. R. O'G. (1999). Indonesian Nationalism Today and in the Future. Indonesia, Vol (67), 1-11. doi:10.2307/3351374.pp. 1

4. Bright, M. (1979). English Literary Romanticism and the Oxford Movement. Journal of the History of Ideas,40(3), 385-404. doi:10.2307/2709244 pp. 386

5. Guérard, A. (1934). Herder's Spiritual Heritage: Nationalism, Romanticism, Democracy. The Annals of the American Academy of Political and Social Science,174, 1-8. Retrieved from http://www.jstor.org/stable/1020510

6. Isnaeni, H. F. (2014, September 1). Setengah Mitos Bambu Runcing. Retrieved from https://historia.id/politik/articles/setengah-mitos-bambu-runcing-vgJ0D

7. Kohn, H. (1950). Romanticism and the Rise of German Nationalism. The Review of Politics, 12(4), 443-472. Retrieved from http://www.jstor.org/stable/1404884

8. Kravitt, E. (1992). Romanticism Today. The Musical Quarterly Vol. 76(1), 93-109. Retrieved from http://www.jstor.org/stable/741914

9. Lanyi, G. (1980). Debates on the Definition of Romanticism in Literary France (1820-30). Journal of the History of Ideas,41(1), 141-150. doi:10.2307/2709108

10. Musnandar, A. (2014). Indonesia: A Country of Challenge. UniversitasBrawijaya Press. p. 83

11. Suryadinata, L. (1978). Indonesian Nationalism and the Pre-War Youth Movement: A Reexamination. Journal of Southeast Asian Studies. Vol 9(1), 99-114. Retrieved from http://www.jstor.org/stable/20070247

12. Susanto, S. (1985). Perjuangan Tentara Pelajar dalam Perang Kemerdekaan Indonesia. Yogyakarta: Gadjah Mada University Press.

13. Tanner, T. (1968). Notes for a Comparison between American and European Romanticism. Journal of American Studies Vol. 2 (1), 83-103. Retrieved fromhttp://www.jstor.org/stable/27552817

14. Van der Kroef, J. (1972). Indonesian Nationalism Reconsidered. Pacific Affairs 45(1), 42-59. doi:10.2307/2755260 